\title{
ENACTMENT AND PUBLICATION OF LAWS IN THE KINGDOM OF NAVARRE
}

\author{
Dr. Fernando de Arvizu y Galarraga \\ University of León \\ Correspondence: \\ farvg@unileon.es \\ Received: \\ 1.10.2020
}

Accepted:

1.11.2020

\section{How to cite this paper}

de Arvizu y Galarra, F. (2020). Enactment and publication of laws in the Kingdom of Navarre. Spanish Journal of Legislative Studies. (2), p.1-9. DOI: https://doi.org/10.21134/sjls.vi2.1284 


\section{SUMMARY}

I-. Concept. II-. Legislative foundations. III-. Legislative procedure in Navarre. Correction regarding Parliamentary. IV-. Factual assumption A: Precedents and first plea to the King B: Second plea to the King. C: Third plea to the King. V-. Conclusions.

\section{Concept}

The development process of a law in Navarre brings to light some particularly interesting features, one of which has still not been studied by the historians of our country: Parliament's power to prevent a law approved by the King from ever coming into force. This was done by not including this approved petition in the documents required so that the Viceroy could sign the General Patent, by which the laws, once published in 'las cabezas de Merindad' (districts) of the Kingdom, would become effective.

This extraordinary limitation of royal power derived from a discretional power of the Three States, which, based on reasons of political prudence, would judge it opportune not to present an approved petition for the Viceroy to sign. But when the Three States were no longer assembled at the time of delivering the 'Roldes' to the Viceroy's prothonotary, it was the Kingdom's Council that had to defend autonomy embodied this time in the sovereign power of Parliament. Besides having irrefutable legal arguments, in our opinion, they had a vitally important means of coercion: the voluntary Donation, whose delivery was per- force delayed until the Patent was duly signed. Once it was signed, the Council would now have sufficient grounds to start collecting the Donation. I say duly signed Patent, because this had to be so under the terms that it was presented, without adding or removing one iota of its content. We will have the opportunity to examine this further at a later point.

\section{Legislative foundations}

The two types of legal foundations of such power are: customary and legal. It should not be forgotten that in Navarre custom is equal to law, and it can even prevail over it. This is based on the fact that, like the law, it is an equally binding legal regulation.

There are few legal bases, since they were created for cases where disagreement about the issue arose. The oldest law is from 1569' ${ }^{1}$, and it establishes that the laws approved at the request of the Three States should be published.

This is the only regulation that can be found on this matter in the 'Novísima Recopilación'. The subsequent regulation is a R. D. from 1726 , which solved a conflict about a matter that arose in the Parliament of Estella from 1724 to 1726 . The Parliament had resolved to withdraw two approved petitions, and the Viceroy refused to sign the Patent unless it contained all the approved petitions. The Council appealed to the King, and he ruled in favour of the Kingdom².

${ }^{1}$ Law 51 of the Parliament of Pamplona of 1569. ELIZONDO, Joaquín de. Recopilación, I, 111, 22, which states: «que de aquí en Adelante las Leyes y Ordenanzas de este Reyno, otorgadas a pedimiento de los Tres Estados del, no se impriman ni manden imprimir si no es a pedimiento de los mismos Tres Estados y Reyno o Síndicos del: y que en lo que se imprimiera no se ponga sino solo lo que se hubiera otorgado, concedido y reparado por suplicación, pedimiento de Ley o reparo de agravio.»

${ }^{2}$ Patent of the Parliament of Estella 1724-1726, found in. BIBLIOTECA DE DERECHO FORAL, Cuadernos de Cortes, I (Pamplona 1964) 145: "Y nuevamente por parte de los dichos Tres Estados se nos pidió y suplicó le mandassemos despachar nuestra Real Provisión por Patente, con inserción de los Pedimentos literalmente arriba expressados, de que se hace mención en el Rolde, que para ello nos fue presentado: Y acordamos y mandamus por Decreto del dicho nuestro llustre Vissorrey Conde de las Torres despachar la mencionada Patente, con que también se incluyesen en ella los Pedimentos decretados y admitidos sobre 
The R. D. of 24th March 1781 refers to this, but its content is questioned. ${ }^{3}$ There was already controversy about it in the Parliament of that time. In this Decree, confirmed by a subsequent plea, the king adhered to the hitherto customary practice. But the Viceroy interpreted this reference as not permitting the withdrawal of the petitions. The Council understood the opposite, since their silence and subduedness on this point cannot be otherwise explained. But when Parliament ended, the matter was returned to and after very long negotiations, it was resolved in favour of the Council on $22^{\text {nd }}$ September of the same year ${ }^{4}$.

Undoubtedly, the law of 1569 provides the bases for drawing general conclusions, since the other regulations are simple resolutions specific to disputes about this matter. Thus, three conclusions can be drawn from the first law mentioned: $1 \mathrm{st}$, in order for the law to be published it had to be at the request of the Three States or the Council; $2^{\text {nd }}$, that in view of the foregoing, the Three States could prevent a law from coming into force by refusing to publish it; 3rd, that rejected petitions could not be published.

\section{Legislative procedure in Navarre. Correction regarding Parliamentary.}

In which case, what was the nature of this act? This requires determining at which exact point of the legislative process it could be carried out. That is to say, as done above, the Parliament could make a law ineffective by failing to publish it; nonetheless, it seems somewhat simplistic at first glance. In fact, this refusal to publish had to be carried out at an opportune moment, and always before the Viceroy signed the General Patent, since the law would then be sanctioned and intangible.

The production process of a law in Navarre is as follows: a) the Parliament approves the legislative petitions;

a) the Parliament approves the legislative petitions:

b) they are submitted to the Monarch, who approves them;

c) once Parliament is dissolved and the Solio is closed, some Roldes are drawn up. They are drawn up by the Three

States and contain the authorized petitions;

d) the Council of the Kingdom is now responsible for delivering the Roldes to the Prothonotary, who in turn will transmit them to the Viceroy, who, previously advised by the Royal Council, will sign the Patent. After this, the laws are now sanctioned. With respect to the Donation, it is acknowledged in the same Patent, so until it is signed, the Council cannot proceed with collecting it;

e) even when the laws have been sanctioned, they do not come into force until their publication, either in print (normal way) or by being read out in the Cabezas de Merindad, which was unusual and was used in the $18^{\text {th }}$ century for reasons of urgency. In previous times, it had been the normal way, and publication was certified on the ori-

insecularse particulares en las Bolsas de Tudela, Sangüesa, Viana, Tafalla, Miranda y Villafranca. Y no habiéndose consentido en esta condición por los dichos Tres Estados, y disuelto las Cortes, se presentó recurso ante nuestra Real Persona por parte de la Diputación de este nuestro Reyno a fin de que mandassemos darle su Patente en la forma. que lo tenía pidido con esclussión de los dichos pedimentos mandados incluir por el llustre nuestro Vissorrey. Y haviendose visto por Nos, y consultando sobre ello por el nuestro Consejo de la Cámara, tuvimos por bien mandar se despache la mencionada Patente en la forma pidida por el Reyno."

${ }^{3}$ A. G. N., ATCTAS DE LA DIPUTACIÓN DE NAVARRA, t. XX, f. 90 r. I must thank my teacher D. Ismael Sánchez Bella who drew my attention to this manuscript from the General Archive of Navarre, since on reading it I was motivated to write this paper. ${ }^{4}$ IBIDEM, ff 128 V.- 130 r. 
ginal document in each cabeza de Merindad, so it therefore contained five certifications ${ }^{5}$.

It was therefore in phase c) when Parliament could decide not to include the petitions that were not going to be published in the Roldes. If they did not do so at that moment, they could no longer change the process, since Parliament was dissolved, and the Council could not exercise any legal discretion in this aspect.

Thus, although approved, these petitions were not published, but the fact is neither were they sanctioned by the Viceroy. The King's approval of a petition should not be confused with its authorization by the Viceroy. When a petition was approved by the King, this did not mean it was raised to the category of law, but it continued to be a petition, which was not binding. This would indicate that on the King's part there was no objection to granting what was requested as long as Parliament wanted to change it into a law later on or render it ineffective.

Once the approved petitions were gathered, it could be observed that several of them should not be converted into laws, and they were therefore not submitted for authorization, which, I repeat, did not correspond to the King but to the Viceroy. The unincluded petitions were not sanctioned and were therefore not published, so they were not binding. This is corroborated by a case that occurred in 1805, whereby the Viceroy asked the Council to send all the Law in force in Navarre. The Council sent him the 'Fuero General', the Novísima Recopilación, the Ordinance of the Council and the Official Parliament Records. Not being satisfied with this, the Viceroy also asked for the rejected or unpublished petitions. In the last document of the dossier, the Council answers the Viceroy in these words: "Las leyes... ., que se dice sancionadas y no publicadas no son leyes, esto es

\footnotetext{
${ }^{5}$ Thus, the original Patent of the approved Laws in Parliament in 1542 1542. A. G. N., sección de ADUANAS, leg. 1, carp. 18.

${ }^{6}$ A. G. N., LEGISLATION section, leg . 22, carp 14.
}

con obligación de tales, ni de ellas se puede hacer mérito auténtico para decidir asuntos de Gobierno." And to corroborate their thesis, the following cases are cited: the one resolved by Felipe II's law of 1569, the case from the Parliament of 1724-26 and the case of $1780-81^{6}$.

The text apparently contradicts all the above-mentioned, but in fact it is a mere transposition of terms. In that period, it was understood that authorization corresponded to the King, but today it is understood that the signee of the law is the one who sanctions it, becoming acquainted with it and ordering it to be complied with and that all the subjects and authorities of the Nation abide by it. Normally, it is now usually the Head of State, but in Navarre this was not the case at that time. The King only approved the petitions which were not yet binding, it cannot be said that he sanctioned them. The person who sanctions them is the Viceroy, because the King is no longer in Navarre to sign the Patent, which cannot be considered therefore a mere order for publication: since if the King were to sanction the petition on approving it and the Viceroy were to simply order it be published, it is impossible to explain how the publication of a sanctioned law could be left to the discretion of Parliament.

Therefore, the reason why these unpublished petitions that the Council talks about are not considered laws is not because they have not been published, but because they have not been sanctioned. In short, everything depends on how the terms are used; but there is no doubt that, having studied the process, and in good legislative terminology, it is incorrect to say that it was the King who sanctioned the laws in Navarre. 


\section{FACTUAL ASSUMPTION}

Such is the theoretical approach of the case. In the last part of this study, we are going to examine a practical case to see whether or not it corroborates what has been discussed so far. We will examine the most interesting and complete case, that of the Parliament of 1780-81, which occurred under the reign of Carlos III.

\section{A. Precedents and first plea to the King}

The Council delivered the Roldes to the Viceroy through the Prothonotary, but because he was taking time his time to return the signed $\mathrm{Pa}$ tent, they wrote to urge that it be resolved soon. But the Viceroy, responding evasively, refused to do so?.

The Viceroy's silence led the Council to appeal to the king to order the immediate return of the signed Patent, which would permit its publication and the immediate delivery of the Donation. At the same time letters were written to the Secretary of State and a friend of the Kingdom to assert their authority before the king $^{8}$.

Meanwhile, the Secretary of State had writ- ten to the Viceroy so that he would communicate to the Council that as it had been two months since the closure of the Solio, the voluntary Donation should be promptly made to the Royal Treasury. The Council defended the correct thesis about the Donation; that is to say, it had to be approved by law and that this law did not exist until the Patent had been signed by the Viceroy and they could therefore not be reproached for anything.

When the 'Cámara de Comptos' (Finance Chamber) heard the answer to the official note sent by their representative, a heated dispute took place. It reached such a point that a judge was required to settle the disagreement, but he resolved to abstain from any procedure, since the matter was in the King's hands. ${ }^{9}$

The appeal was sent on $6^{\text {th }}$ July. On the $11^{\text {th }}$ August a letter from the Secretary of State was received indicating that he had carried out the commissioned task and that the King had ordered the signed Patent to be returned for its publication. But the King's resolution was completely different. The Viceroy, who communicated it, qualified the appeal as "pretestos frívolos", and that the King had decided that the Patent

${ }^{7}$ A. G. N., ACTAS DE LA DIPUTACIÓN DEL REINO DE NAVARRA, t. XX, ff. 69 v. 74 r. In fact on 3rd June the Council delivered the Roldes through the Prothonotary Juan de Larramend. On the 30th, an official note was sent to the Viceroy and "rogándole que le passase firmada la Patente para facilitar su impression y poder hacer efectiva la entrega del donativo voluntario". The Viceroy answered the Council on 3rd July, telling them not to be in such a hurry, since it had been less than two months and the report by the advisors required time.

A letter from the Council dated 4th July said that given their faith in the Prothonotary there was no doubt about the identity of the originals, and it was superfluous to collate them and that although this were done, it would not require so

much time that it would disrupt other matters and it insisted that without the Patent, the Donation could not be delivered.

${ }^{8}$ IBIDEM. ff . 75 r.- 78 v. The letter to the Secretary of State, Miguel de Múzquiz, was very discreet, since it only asked for him to try and influence the Monarch's intention. The letter to Pedro de Lavaire explains that the Council could be confident in their appeal to the King, but it preferred to ask for his support.

9 IBIDEM, ff. 85 r. 89 . The Council's course of action of asking for the Patent before two months had passed seems strange, since it does not seem plausible that it should want to deliver the donation as soon as possible. In fact, what happened was that the Council guessed that difficulties would arise if a thorough examination was made of the Roldes. It would be discovered that some of the petitions were missing, in which case the King would be forced to make a decision about the matter. This would mean that there was an enormous danger that Parliament's power to withdraw petitions would not be acknowledged, and consequently their autonomy would be compromised. If the Viceroy signed the Patent, there would be a different argument based on custom. 
should not be signed until all the petitions to be excluded from the Patent were submitted, since they had infringed a Decree of $24^{\text {th }}$ March and the Laws of Kingdom.

\section{B. Second plea to the King}

The Council was not satisfied with such a reply, so it submitted a very lengthy plea for the second time. It starts by talking about the Decree of $24^{\text {th }}$ March 178I, which, according to the Viceroy, prevented access to the Council's petitions. The Decree, it concludes, referred to the accustomed practice, a tenet confirmed by the Royal resolution of $28^{\text {th }}$ March, which corroborates it. Otherwise, the Council would have petitioned until it achieved its purpose. It further recalls laws that support the rectitude of its position and numerous examples of loyalty to the King.

Likewise, it sent letters to the Secretary of State, to their previously mentioned supporter and to the Agent in Madrid, giving him specific instructions. Further still, it also sent letters to the Viceroy, saying, among other points, that the Viceroy himself had sent notices to the Parliament on $17^{\text {th }}$ March so that all the petitions and resolutions adopted should be inserted in the General Patent of laws. This harmed the customary law, and therefore it was appealed before the King who responded through the cited Decree of $24^{\text {th }}$ March $1781^{10}$.

Through the Secretary of State, the Council heard somewhat later that the King did not agree to the request, and likewise ordered that the Donation should be promptly made, since there was a long delay. In the same date, the official notification was received through the Viceroy, which contained the King's reasoned resolution. It concluded by saying Felipe II's law of 1569 was not violated, since no other petitions were published except those approved by the King; therefore, the Cortes could not withdraw them ${ }^{11}$. The Viceroy, therefore, urged them again for the prompt delivery of the Donation.

The argument is very weak and lies in a distorted interpretation of the law which only orders the approved laws petitioned by the Three States to be printed by their explicit request or that of the Council. The royal judgement does

${ }^{10}$ IBIDEM, ff 90 r.- 109 r. The appeal is the 14th August, and for its regulatory foundations, it cites Felipe II's law of 1569 and the RC resolving an analogous case that occurred in the Parliament of Estella, dated 2nd June 1726, The letter to D. Miguel de Múzquiz is written in a different style to the previous one. It outlines how an immemorial custom has been violated and concludes saying: "El pedirme que de mí se alarguen al Protonotario los pedimentos de leyes que no comprendió en Reyno es pedirme un imposible: son limitados mis poderes y no puedo trascender de ellos un ápice." The second letter is addressed to D. Pedro Lavaire in similar terms.

The letter that provides greatest interest is the one to the Agent of the Kingdom in the Court of Castille, in which, after outlining the reasons and aims of the document, it informs that the Agent's mission will be to convince them that the claims, which they have an opposite view of, are justified. Beside this, it orders him to find out everything and try to avail himself of those in favour of the Kingdom, especially Lavaire and Azpírce, before giving the letter to Músquiz. And if in his opinion there is a long delay before a resolution is reached, then he should abstain from presenting the appeal for now and report on everything that happens. The letter to the Viceroy of the same date as the appeal also contains strong phrases against him. After saying that they could not reconcile what the King said on 24th and 28th March with the order from the Viceroy, they label it as inadmissible that he should qualify the practice followed till then as "abuso intolerable". With respect to the R.C. of 1726, it says: "si después de haberlos aceptado declare el Rey ser libre de los Tres Estados retirarlos, superior motive hay ahora para no inserter en la Patente otras leyes que las especificadas en los Roldes, pues ningunas otras han sido aceptadas." Neither could the Viceroy affirm that the Council delayed the donation with frivolous pretexts.

${ }^{11}$ IBIDEM, ff. 111 r. 112 v Both the unofficial letter from D. Miguel de Múzquiz, Secretary de State and the from the Viceroy are dated 1st September. After communicating the resolution, the Viceroy ratifies everything previously said about the Patent and the previous plea. 
sustain that it was the King who converted a petition into a law on acknowledging it; that is to say, he sanctioned it. In any event, such a judgment does not seem correct, since if the King sanctioned the law, it is impossible to reasonably explain how the explicit agreement of Parliament or the Council was required for a sanctioned law to be published (as the law states), thereby putting its enforceability in danger. Besides, the R. C. of $2^{\text {nd }}$ June 1726 contradicts such a stance. It is also curious that in this case the petitions had not been approved by the King, in contrast to what happened with the Parliament of Estella from 1724 to 1726 , although the truth is that neither of the two parties gave importance to this point again in the next plea.

\section{Third plea to the King}

The third plea by the Council was sent on the same date as the royal resolution was recei- ved. It starts by talking about the Decree of $24^{\text {th }}$ March repeating what was said in the previous plea. But now, leaving out the predominantly legal terms that it used before, it focuses on the matter from a political point of view ${ }^{12}$.

As before, the Council sent letters of recommendation as always to the Secretary of State and others in favour of the Kingdom ${ }^{13}$. On the same date, that is to say, on1st September, the Council sent a an official note to the Valles in a peremptory tone, ordering the following: "en atención a no haberse verificado hasta ahora la publicación de la Patente General de las Leyes de las últimas Cortes, se escriva carta circular a los Valles y pueblos del Reino, previniéndoles que sin embargo del aviso y orden que se les comunicó para el cobro de la cantidad repartida anteriormente por fuegos, no se adelanten a exigirla, antes suspendan el hacerlo hasta nuevo aviso, respect de que la ley del Servicio no lo es, assí como ninguna otra, ni merecen tal nombre antes de publicarse" 14 .

${ }^{12}$ IBIDEM, ff. 112 v.- 116 r. Most of the plea is aimed at influencing royal intentions. Firstly, it reminds him of Navarre's loyalty to his predecessors, who on their part had respected the laws of Navarre. Even the King himself, in his oath, had stated his commitment to not make laws that would contradict the customs of the Kingdom, by which his "omnipotente poder se hallaba enlazado en Navarra con sus venerables fueros y patrias leyes". Apart from this, the Council explains its position: because of its oath to Parliament, it cannot admit the Patent of laws in any other form that that in which the Three States requested and obtained them, since in any other way it would be acting beyond its functions. By virtue of the aforementioned and actions taken, it is free from its responsibility for not having delivered the Donation before. It cites the law as we already know; that of Felipe II of 1569, the R.C. of Felipe V of 2nd June of 1726 and the royal resolution of 28th March 1581.

${ }^{13}$ IBIDEM: ff. 116 v., $118 \mathrm{v}$. In the letter to the Secretary of State it is said that in Pamplona there was "alguien con siniestras intenciones que estaba fomentando ese resultado", referring to the previous decision. Who could it be? It cannot be said exactly. But it is likely, or at least possible that it was the Viceroy, given the animosity that he shows he with respect to the Council's activity.

At the same time, a letter was sent to a long list of supporters of the Kingdom. The letter explains the legislative procedure in Navarre: the petition is presented, the King or the Viceroy issues a ruling, accepting, refusing or modifying it. When Parliament is dissolved, it requests the general provision of the Patent comprising those laws that it has resolved to be included, creating a specific Rolde. And if the Parliament considers that they should withdraw some petitions, before adjourning the Solio, they are able to do so. The letter informs the addressee of the background of the ongoing enquiry and asks for their support against those who aim to conceal what is right.

The list is very interesting, since it shows who in the Court are supporters of the Kingdom. The letter is sent to: Excmos. Sres. Duque de Alba, Duque de Granada de Ega, Marqués de Castejón, and D. Silvestre Abarca. IImo Sr. D Juan de Azado Rico, Arzobispo de Tebas, confessor to the Rey. He was written a separate letter so that he could influence the Kings's intention on the basis of his Oath to the Kingdom and that of the Council to Parliament. And Señores D. Juan Manuel de Mendmueta y Múzquiz, D. Joaquín García Orobio, D. Francisco Arguedas, D. Julián de San Cristóbal, Conde de Saceda, D. Josef de Bermuda, D. Fernando Daoiz, D. Josef de Ybarra and D. Juan Esteban de Salaberri.

${ }^{14}$ BIDEM, ff 119 V. 120 r. 


\section{ENACTMENT AND PUBLICATION OF LAWS IN THE KINGDOM OF NAVARRE \\ Dr. Fernando de Arvizu y Galarraga}

The following day another letter is received from the Viceroy, addressed to the Council and prior to the notification of the Royal resolution. Strong words were used by both parties, repeating the same interpretations of the cited regulations ${ }^{15}$

Days later an unofficial notification was received from the Secretary of State communicating that the King agreed to the request "más por afecto y benignidad que por razones teóri- cas". Later the official notification was received through the Viceroy. This gave rise to an active correspondence. On the one side, the Council answered the Viceroy's letter, and on the other, it addressed different letters to the Secretary of State and a supporter explaining the efforts and actions taken by the Council in dealing with the petition. At last, the Prothonotary delivered the Patent duly signed and the Council took measures for the speedy collection of the Donation ${ }^{16}$.

${ }^{15}$ IBIDEM, ff 120 r.- $125 \mathrm{~V}$.

${ }^{16}$ IBIDEM, ff. 128 v.- 134 v. The letter from D. Miguel de Múzquíz also contained a request for the prompt delivery of the donation. This was dated 20th September.

On 22nd the Viceroy's letter was received. It simply added to the resolution that he had passed on the Patent of laws to the Prothonotary for it to be duly delivered.

On the same day, the Council answered, also in plain terms "y enterado de la Real determinación, queda esperando ponga el Protonotario la Patente en mis manos para hacer, en consecuencia, lo que me incumbe."

On the same day the Council wrote a letter to D. Miguel de Múzquiz and to D. Javier de Azpiroz in the following tone: “Illmo. Sr. Muy Sr. mío Este rasgo de beneficencia, propio de la incomparable piedad y justificación de S. M., es conforme a la confianza que me inspiraba su Real benignidad, y conducido de su impulso, y no menos de los generosos estímulos de mi fidelidad e innata propensión a cuanto redunda en su Real servicio; desde el punto en que llegó a mis manos el pliego de V. E., he dedicado toda mi atención al acopio de las cantidades del donativo que en las últimas Cortes ofrecieron al Rey los Tres Estados, y, sin embargo, de que hasta ahora no se me ha pasado la Patente, y de que me sería incomparablemente más fácil el apronto satisfaciendo el importe en villetes, considerando será más grato al obsequio a S. M. si se le entregase en real, verdadera moneda, he podido conseguir, a expensas del desvelo que tan justament me merece tal cuidado, proporcionar las cosas de manera que me lisongeo con la satisfacción de que han de lograrse cumplidamente las soberanas intenciones. Y asegurando que después del Rey (Dios le guarde), es V. E., el único a quien debo haya sido atendida mi justicia, le rindo las más expresivas gracias por esta señalada merced, que vinculará eterno mi reconcimieto, y el de todo el Reyno a tan justa, generosa demostración." 24th September the Prothonotary delivered the duly signed Patent. The Council wrote to the Viceroy on the same day that in order to save time and without setting a precedent, it had resolved to publish the Patent in the cabezas de Merindad and in Pamplona, instead of printing it, subject to his superior criteria. The Viceroy showed his satisfaction, praising, the "celo y amor de la Diputación de tan antiguo acreditados".

On an anecdotal level, it seems appropriate to present the outcome of this matter, since from an informative point of view it is invaluable. On 27th September, the Council wrote to the Agent so he would thank those who intervened in the matter, especiaIly D. Pedro Custodio de Echevarría and D. Manuel de Alzpún.

On 4th October the donation, which reached the sum of three hundred thousand pesos, was finally delivered before D. Antonio de Riezu, Royal Scribe, who acted as witness. The Royal Treasurer, D. Josef Martín de Virto, issued a certificate of payment, a legalized copy of which was sent to the Secretary of State.

Likewise, on 9th October the Council agreed to write to Señores Abarca, Cristobál, Salabem and Mendinueta, who had intervened in the matter and had congratulated the Council. The letter was written as follows: " M. I. Sr. Muy Sr mío. Me es de singular estimación la enhorabuenna con que me felicita V. S. por el éxito que ha logrado la tercera instancia, con que he reclamado la piedad del Rey a fin de que en la impression y publicación de la Patente de Leyes de las últimas Cortes se guardasen religiosamente sus Leyes, Fueros y constante práctica, y habiendo contribuido los esmeros de V. S. a suceso tan favorable, y lo mucho que se interesa como tan buen patriota en las felicidades de Navarra, le retribuyo el parabién y repetidas gracias por la fineza con que ha sabido distinguirse V. S. en facilitar una resulta tan deseada, y de importancia muy transcendental en las apreciables libcrtades de este Reyno, y para manifestarle mi gratitud, tendré especial gusto en que $\mathrm{V}$. S. me proporcione ocasiones mayor satisfacción." (IBÍDEM 132 v. ${ }^{\circ}-135$ v. ${ }^{\circ}$ ).

Finally, in $\mathrm{f} 141 \mathrm{v}$ there is a letter from the Agent in Madrid dated 19th November, written as follows. "dado que han trabajado en este asunto para los negocios del Reyno personas a las que no es decente regalar otra cosa que frutos del país, se resolvió enviar seis cargas de vino rancio, tres en barriles y tres en pellejos". 


\section{Conclusions}

In the colophon to this study, it only remains to add the following conclusions:

Firstly, it seems to be demonstrated that royal power could be restricted by Parliament, which exercised this power for reasons of political prudence particularly in the legislative aspect. In the same token, in the Patent, it was only necessary to include the approved or at least partly modified petitions.

Secondly, that this power came up against a marked Bourbon absolutism in legislative matters. To counteract this tendency, it was necessary to use indirect coercion, since legal arguments were not listened to. And the means of achieving this was by delaying the delivery of the voluntary Donation for as long as the Patent was not signed, which powerfully influenced the attitude of the governors of the Court, although both parties took great care to keep up appearances. 